\title{
PENGARUH PENAMBAHAN IKAN LEMURU (Sardinella longiceps) TERHADAP KARAKTERISTIK FOLIKEL DAN SIKLUS OVULASI PADA AYAM RAS PETELUR
}

\author{
Amiluddin Indi ${ }^{1}$,Dian Agustina ${ }^{1}$, R. Erna ${ }^{2}$ \\ ${ }^{1)}$ Fakultas Peternakan Universitas Halu Oleo Kendari \\ ${ }^{2)}$ Fakultas Peternakan Universitas Diponegoro
}

\begin{abstract}
ABSTRAK
Penelitian ini bertujuan untuk mengetahui pengaruh penggunaan minyak ikan lemuru dalam ransum sebagai upaya untuk meningkatkan karakteristik folikel, siklus ovulasiserta mencari taraf optimal minyak ikan lemuru dalam ransum. Penelitian dilakukan di Balebat Farm, Desa Sukorejo, Kabupaten Kendal.Materi yang digunakan 180 ekor ayam petelur umur 22 minggu dengan bobot awal rata-rata $1.745,2 \pm 8,26 \%$. Ransum yang digunakan disusun berdasarkan isoprotein. Rancangan percobaan yang digunakan adalah Rancangan Acak Lengkap (RAL) dengan 5 perlakuan yang terdiri atas $\mathrm{R}_{0}$; ransum dasar tanpa penambahan minyak ikan lemuru, $\mathrm{R}_{1}$ : ransum dasar + minyak ikan lemuru $1,5 \% ; \mathrm{R}_{2}$ : ransum dasar + minyak ikan lemuru $3 \% ; \mathrm{R}_{3}$ : ransum dasar + minyak ikan lemuru 4,5\%; $\mathrm{R}_{4}$ : ransum dasar + minyak ikan lemuru $6 \%$. Setiap perlakuan diulang 6 kali, dan setiap unit percobaan diisi 6 ekor ayam periode layer. Data yang diperoleh diolah secara statistik dengan analisis ragam dilanjutkan dengan Uji Jarak Berganda Duncan.Hasil penelitian menunjukkan bahwa penambahan minyak ikan lemuru dalam ransum berpengaruh tidak nyata $(P>0,05)$ terhadap karakteristik folikel yang meliputi bobot ovarium dan folikel serta dan jumlah bobot folikel dengan diameter $\geq 1 \mathrm{~cm}$. Hasil analisis menunjukkan bahwa penambahan minyak ikan lemuru dalam ransum berpengaruh nyata $(\mathrm{P}<0,05)$ mempercepat siklus ovulasi, dengan data berturut-turut dari $\mathrm{R}_{0}$ sampai $\mathrm{R}_{4}$ adalah 23,$64 ; 24,27 ; 24,12 ; 23,84 ; 23,47$ (jam). Kesimpulan hasil penelitian ini adalah bahwa penambahan minyak ikan lemuru dalam ransum mempercepat waktu siklus ovulasi. Penambahan minyak ikan lemuru dalam ransum sampai $6 \%$ dapat digunakan untuk ayam petelur periode layer.
\end{abstract}

Kata Kunci : Minyak Ikan Lemuru, Karakteristik Folikel, Siklus Ovulasi

\begin{abstract}
This study aims to determine the effect of lemuru fish oil in the diet an effort to improve the characteristics of the follicle, ovulation cycle and to find the optimal level of lemuru oil in the ration. The study was conducted in Balebat Farm, Village Sukorejo, Kendal. Materials used 180 laying hens aged 22 weeks weigh rate were $1745.2 \pm 8.26 \%$. Rations used is based isoprotein. The experimental design used was completely randomized design (CRD) with five treatments consisting of R0; basic ration without the addition of lemuru fish oil, R1: basic ration $+1.5 \%$ lemuru oil; R2: basic ration + $3 \%$ lemuru oil; R3: basic ration $+4.5 \%$ lemuru oil; R4: basic ration $+6 \%$ lemuru oil. Each treatment was repeated six times, and each experimental unit filled six periods layer chickens. The data obtained were processed statistically by analysis of variance followed by Duncan's Multiple Range Test. The results showed that the addition of lemuru fish oil in the diet not affect significantly $(\mathrm{P}>0.05)$ on the characteristics of follicles. The analysis showed that the addition of lemuru fish oil in the diet significant effect $(\mathrm{P}<0.05)$ accelerate the ovulatory cycle, with a row of data from R0 to R4 is 23.64 ; $24.27 ; 24.12 ; 23.84 ; 23.47(\mathrm{~h})$. The conclusion of this study is that the addition of lemuru fish oil in the diet accelerate the cycle time of ovulation. The addition of $6 \%$ lemuru fish oil in the diet can be used for laying hens layer period.
\end{abstract}

Keywords: Lemuru Oil, The Characteristics Of The Follicle, Ovulation Cycle 


\section{PENDAHULUAN}

Ayam petelur merupakan salah satu komoditas ternak yang dapat dijadikan sarana pemenuhan kebutuhan protein. Telur merupakan bahan makanan yang banyak memegang peranan penting di dalam membantu mencukupi kebutuhan gizi dimana protein telur termasuk jenis protein hewani berkualitas tinggi dengan kandungan protein yaitu $12 \%$ dan lemak 11 $\%$ (Amrullah,2003). Ada anggapan bahwa telur merupakan bahan pangan yang dapat menimbulkan penyakit aterosklerosis karena adanya kandungan lemak dan kolesterol yang tinggi dalam telur. Oleh karena itu untuk memberikan rasa aman pada konsumen telur, dilakukan berbagai terobosan untuk mencari alternatif yang dapat meningkatkan kualitas telur yaitu telur yang mempunyai kandungan omega-3 dan kolesterol yang rendah. Kandungan kolesterol telur cukup tinggi yaitu sebesar 200-250 mg/butir dan kandungan omega-3 nya relatif rendah (Jiang dan Sim 2000, Griffin 2001).

Minyak ikan lemuru (Sardinella longiceps) merupakan limbah hasil pengolahan ikan lemuru dari proses pengalengan dan proses pembuatan tepung ikan, penggunaannya kurang berkompetisi dengan manusia. Setiap $1 \mathrm{~kg}$ ikan lemuru akan di peroleh $0,2 \mathrm{~kg}$ minyak ikan (Kompiang et al., 2001). Perairan Muncar Kabupaten Banyuwangi sebagai daerah penangkapan utama ikan lemuru, pada tahun 1994 mempunyai produksi ikan lemuru rata-rata per tahun mencapai \pm 30.750 ton dan $93 \%$ dari seluruh tangkapan adalah ikan lemuru dengan jumlah perkiraan pasokan minyak lemuru pertahun rata-rata \pm 6.150 ton (Suhermiyati, 2004).

Penggunaan minyak ikan lemuru dalam ransum ayam petelur selain berfungsi sebagai sumber asam lemak omega-3 juga dapat meningkatkan kualitas telur dan produksi telur (Hargis, 2002). Kolesterol merupakan precursor semua senyawa steroid dalam tubuh seperti hormone seks, asam empedu, vitamin $\mathrm{D}$, serta senyawa lipoprotein bahan penyusun sel yang dibutuhkan tubuh dan diperlukan ternak untuk keperluan reproduksi atau pembentukan telur (Griffin 1998; Murray et al., 1999).Minyak ikan lemuru dalam ransum ayam, baik pada ayam petelur maupun broiler dengan penggunaan minyak ikan lemuru 3-6\% memberikan pengaruh yang baik terhadap penampilan lemak, kolesterol, serta omega-3 dan omega-6, juga memberikan pengaruh yang baik pada produksi telur (Supadmo, 2005). Hal ini tersebut didukung oleh beberapa peneliti diantaranya Leskanich dan Nobel, (1997) ; Ikrawan (2002) menyatakan, omega-3 dalam minyak ikan dapat merangsang produksi hormon-hormon yang berfungsi sebagai anti agregator, yaitu anti penggumpalan darah pada arteri (Ikrawan, 2002) disamping itu hormon-hormon tersebut diperlukan bagi perkembangan folikel.

\section{METODE PENELITIAN}

\section{Lokasi dan Waktu Penelitian}

$\begin{array}{lllr}\text { Penelitian tentang } & \text { pengaruh } \\ \text { penambahan minyak } & \text { ikan } & \text { lemuru } \\ \text { (Sardinella longiceps) } & \text { dalam } & \text { ransum }\end{array}$ terhadap perkembangan folikel dan siklus ovulasi serta performans produksi pada ayam ras petelur strain Lohmann Brown telah dilaksanakan pada tanggal 26 Juni sampai 5 Oktober 2010 dengan mengambil tempat pelaksanaan di Balebat Farm, Desa Sukorejo, Kecamatan Sukorejo, Kabupaten Kendal.

\section{Materi dan Metode}

Materi penelitian yang digunakan adalah ayam petelur strain Lohmann Brown periode layer umur 22 minggu sebanyak 180 ekor dengan bobot badan awal rata-rata 
$1.745,2 \mathrm{~g} \pm 8,26 \%$ yang dipelihara sampai umur 36 minggu. Ransum yang digunakan selama penelitian adalah iso protein dengan tingkat energi metabolis yang berbeda (protein kasar dengan kisaran 21,09 \% 21,40 \%) dan kandungan energi bervariasi dari $2.723 \mathrm{kkal} / \mathrm{kg}$ sampai $3.362 \mathrm{kkal} / \mathrm{kg}$ ). Ransum yang digunakan pada penelitian ini terdiri dari Ro (Ransum dasar tanpa penambahan minyak ikan lemuru), $\mathrm{R}_{1}$ (Ransum dasar + minyak ikan lemuru 1,5 $\%$ ), $\mathrm{R}_{2}$ (Ransum dasar + minyak ikan lemuru $3 \%$ ), $\mathrm{R}_{3}$ (Ransum dasar + minyak ikan lemuru 4,5\%) dan $\mathrm{R}_{4}$ (Ransum dasar + minyak ikan lemuru $6 \%$ ). Pemberian ransum maupun air minum dilakukan $a d$ libitum. Penambahan pasir dalam komposisi ransum penelitian bertujuan sebagai bahan pengisi untuk melengkapi jumlah $106 \%$ pada masing-masing ransum perlakuan.
Kandang ayam yang digunakan sebanyak 180 unit dengan model battery terbuat dari kawat, masing-masing petak berukuran panjang $18 \mathrm{~cm}$, lebar $40 \mathrm{~cm}$ dan tinggi $45 \mathrm{~cm}$ yang dilengkapi dengan tempat pakan dan minum dari PVC pralon dan setiap petak diisi 1 ekor ayam.

Penelitian menggunakan metode eksperimental dengan rancangan penelitian adalah Rancangan Acak Lengkap sederhana (RAL) dengan 5 perlakuan yang masingmasing diulang 6 kali. Setiap unit ulangan masing-masing terdiri dari 6 ekor ayam periode layer. Sebagai perlakuan adalah taraf penambahan minyak ikan lemuru yaitu $0 ; 1,5 ; 3 ; 4,5 ; 6 \%$ pada ransum basal dan masing-masing diberi notasi $\mathrm{R}_{0}, \mathrm{R}_{1}, \mathrm{R}_{2}, \mathrm{R}_{3}$, $\mathrm{R}_{4}$.

Tabel 1. Komposisi dan Analisis Kimia Ransum Penelitian

\begin{tabular}{|c|c|c|c|c|c|}
\hline Bahan pakan & $\mathrm{R}_{0}$ & $\mathrm{R}_{1}$ & $\mathrm{R}_{2}$ & $\mathrm{R}_{3}$ & $\mathrm{R}_{4}$ \\
\hline Jagung kuning & 53,31 & 53,31 & 53,31 & 53,31 & 53,31 \\
\hline Bungkil kedele & 25,15 & 25,15 & 25,15 & 25,15 & 25,15 \\
\hline Meat bone meal & 1,00 & 1,00 & 1,00 & 1,00 & 1,00 \\
\hline Poultry meat meal & 8,80 & 8,80 & 8,80 & 8,80 & 8,80 \\
\hline Dedak padi & 2,00 & 2,00 & 2,00 & 2,00 & 2,00 \\
\hline Kulit kerang & 9,00 & 9,00 & 9,00 & 9,00 & 9,00 \\
\hline Premix & 0,70 & 0,70 & 0,70 & 0,70 & 0,70 \\
\hline Methionin & 0,04 & 0,04 & 0,04 & 0,04 & 0,04 \\
\hline Minyak ikan lemuru & 0,00 & 0,00 & 0,00 & 0,00 & 0,00 \\
\hline Pasir & 6,00 & 4,50 & 3,00 & 1,50 & 0,00 \\
\hline \multicolumn{6}{|l|}{ Analisis Kimia } \\
\hline $\operatorname{Air}^{* * *}$ & 10,74 & 10,82 & 9,63 & 10,52 & 10,50 \\
\hline $\mathrm{ME}(\mathrm{kkal} / \mathrm{kg})^{*}$ & 2723 & 3005 & 3124 & 3242 & 3362 \\
\hline Protein kasar $(\%)^{* *}$ & 21,09 & 21,38 & 21,38 & 21,40 & 21,22 \\
\hline Lemak kasar $(\%)^{* *}$ & 3,75 & 6,97 & 6,40 & 6,87 & 8,63 \\
\hline Serat kasar $(\%)^{* *}$ & 6,98 & 2,76 & 4,75 & 4,01 & 2,05 \\
\hline $\mathrm{Abu}^{* *}$ & 13,77 & 9,45 & 12,50 & 11,08 & 9,04 \\
\hline $\mathrm{Ca}(\%)^{* *}$ & 2,24 & 2,20 & 2,15 & 2,15 & 2,16 \\
\hline $\mathrm{P}(\%)^{* *}$ & 0,29 & 0,28 & 0,26 & 0,26 & 0,25 \\
\hline EPA $^{* *}$ & _- & 6,34 & 5,56 & 6,15 & 6,85 \\
\hline $\mathrm{DHA}^{* *}$ & & 4,38 & 3,89 & 4,57 & 5,05 \\
\hline
\end{tabular}


Penelitian ini diawali dengan tahap persiapan kandang yang meliputi penenataan, pembersihan dan dilanjutkan dengan penyemprotan kandang dengan menggunakan desinfektan. Pemberian vitamin elektrolit diberikan 1 hari sebelum ayam masuk dalam kandang penelitian dan 2 hari setelah ayam masuk dalam kandang penelitian. Penelitian pendahuluan dimulai pada saat umur 22 minggu dengan pemberian ransum kontrol untuk menyeragamkan kondisi ternak sebelum diberikan penambahan minyak ikan lemuru.

Parameter yang diamati meliputih karakteristik folikel, dan siklus ovulasi.Pengamatan karakteristik folikel dilakukan dengan pembedahan ayam yang diambil dari setiap perlakuan sebanyak empat ekor ayam pada akhir penelitian (ayam umur 36 minggu). Karakteristik folikel diukur dengan cara menimbang bobot ovarium bersama folikelnya serta menghitung jumlah bobot folikel yang mempunyai ukuran diameter tidak kurang dari $1 \mathrm{~cm}$.

Siklus ovulasi, diperoleh dengan cara mengukur secara praktis, dihitung berdasarkan interval waktu dari bertelur pertama sampai pada waktu bertelur berikutnya atau antar oviposisi (jam) Nesheim et al., (1999). Masing-masing perlakuan diambil 6 ekor ayam secara acak, pengamatan siklus ovulasi dilakukan selama tujuh hari.

\section{Analisis Data}

Data penelitian yang diperoleh dianalisis dengan analisis ragam pada taraf signifikasi 5 persen, kemudian dilanjutkan dengan uji jarak berganda Duncan apabila terdapat perbedaan yang nyata antar perlakuan (Steel dan Torrie, 1991). Data diolah menggunakan program komputer aplikasi SAS (Statistical Analysis System).

\section{HASIL DAN PEMBAHASAN}

\section{Bobot Ovarium dan Folikel}

Variabel pengamatan terhadap karakteristik folikel meliputi bobot ovarium dan folikel, serta jumlah dan bobot folikel yang mempunyai ukuran diameter tidak kurang dari $1 \mathrm{~cm}$, untuk lebih jelasnya dapat dilihat pada tabel 2 .

Bobot ovarium dan folikel selama penelitian untuk $\mathrm{R}_{0}, \mathrm{R}_{1}, \mathrm{R}_{2}, \mathrm{R}_{3}$ dan $\mathrm{R}_{4}$ mempunyai rata-rata yaitu sebesar 52,41; 52,07; 52,32; 52,34; 52,55 g (tabel 2).

Penambahan minyak ikan lemuru pada ransum tidak berpengaruh nyata ( $\mathrm{P}>0,05)$ pada bobot ovarium dan folikel. Kemungkinan hal ini disebabkan periode pertumbuhan organ reproduksi pada periode layer sudah optimum, sehingga penambahan minyak ikan lemuru dalam ransum hasilnya tidak jauh berbeda, hanya bersifat membantu memaxsimumkan kemampuan perkembangan organ reproduksi dari individu ayam tersebut. Bobot ovarium dan folikel sangat ditentukan oleh jumlah dan bobot folikel yang sedang tumbuh, dan besar ukurannya proporsional.

Tabel 2. Pengaruh Perlakuan Terhadap Jumlah dan Bobot folikel serta Siklus Ovulasi

\begin{tabular}{|l|l|l|l|l|l|c|}
\hline \multicolumn{1}{|c|}{ variabel } & \multicolumn{1}{c|}{$\mathbf{R}_{\mathbf{0}}$} & \multicolumn{1}{c|}{$\mathbf{R}_{\mathbf{1}}$} & \multicolumn{1}{c|}{$\mathbf{R}_{\mathbf{2}}$} & \multicolumn{1}{c|}{$\mathbf{R}_{\mathbf{3}}$} & \multicolumn{1}{c|}{$\mathbf{R}_{\mathbf{4}}$} & Signifikan \\
\hline Bobot ovarium dan folikel (g) & 52,41 & 52,07 & 52,32 & 52,34 & 52,55 & NS \\
\hline Jumlah folikel $\geq 1 \mathrm{~cm}$ (butir) & 6,25 & 5,50 & 5,75 & 6,00 & 6,50 & NS \\
\hline Bobot folikel $\leq 1 \mathrm{~cm}(\mathrm{~g})$ & 34,30 & 32,25 & 32,49 & 33,90 & 34,83 & NS \\
\hline Siklus ovulasi (jam) & $23,60^{\mathrm{cd}}$ & $24,27^{\mathrm{a}}$ & $24,12^{\text {ab }}$ & $23,84^{\mathrm{bc}}$ & $23,47^{\mathrm{d}}$ & $\mathrm{S}$ \\
\hline
\end{tabular}

Keterangan : Superskrip berbeda pada baris yang sama menunjukkan perbedaan yang nyata $/ \mathrm{S}(\mathrm{P}<0,05) \mathrm{NS}:$ Tidak nyata 
Hal ini sesuai dengan pendapat Moreng dan Avens (1998), Nesheim et al. (1999) yang menyatakan bahwapertumbuhan organ reproduksi mencapai puncaknya saat menjelang pubertas sekitar 20 minggu, dan dinyatakan pula bahwa selama periode produksi pertumbuhan organ reproduksi relative konstant. Pendapat tersebut didukung oleh Kwakkel et al (1993)yang menyatakan bahwa perkembangan "yolk" yang cepat berlangsung sekitar 7-12 hari menjelang pubertas, ukuran mencapai maxsimum selama periode produksi berlangsung sekitar 12 bulan, setelah itu akan mengalami regresi selama periode istrahat atau molting. Dinyatakan juga Moreng dan Avens (1998); Nesheim et al. (1999)bahwa saat produksi, ovarium bobotnya relatif konstan, yaitu $\pm 6,0 \mathrm{~g}$ dan bersama folikel bobotnya $\pm 52,3 \mathrm{~g}$. Bobot ovarium dipengaruhi oleh bobot folikel yang sedang tumbuh.

Bobot ovarium dan folikel terbesar dicapai perlakuan ransum $R_{4}$ yang mendapat penambahan minyak ikan lemuru tertinggi $(6 \%)$ kemudian diikuti oleh $\mathrm{R}_{0}$, $\mathrm{R}_{3}, \mathrm{R}_{2}$, dan $\mathrm{R}_{1}$ (Tabel 2). Perlakuan ransum $\mathrm{R}_{4}$ walaupun mempunyai bobot ovarium dan folikel terbesar, tetapi belum sampai menyentuh pengaruh yang nyata tingkat signifikan $(\mathrm{P}<0,05)$. Hal ini menunjukan walaupun konsumsi ransum pada perlakuan ransum $\mathrm{R}_{4}$ paling rendah tetapi konsumsi lemak dan asam-asam lemak tertentu dalam ransum lebih tinggi, sehingga hal ini dapat membantu meningkatkan bobot ovarium dan folikel. Perlakuan pada ransum $\mathrm{R}_{1}, \mathrm{R}_{2}$ dan $R_{3}$ mempunyai bobot ovarium dan folikel yang lebih rendah dari ransum control $\left(\mathrm{R}_{0}\right)$, hal ini disebabkan konsumsi ransumnya lebih rendah sehingga cadangan zat nutrisi protein sebagai bahan utama pembentukan yolk atau folikel lebih sedikit dibanding $\mathrm{R}_{0}$ (Lampiran 2).Hal ini sesuai dengan hasil penelitian Nesheim et al.
(1999) bahwa produksi telur sangat dipengaruhi oleh tercukupinya kandungan nutrisi ransum yang diberikan sehingga menyebabkan proses metabolism berjalan secara optimal, dan hal ini berdampak pada jumlah folikel lebih banyak.

Bobot ovarium dan folikel yang meningkat berdampak pada produksi telur yang tinggi, sehingga hal ini akan memacu siklus ovulasi yang cepat pula hal ini seiring dengan siklus ovulasi dan produksi yang dihasilkan selama penelitian. Pendapat tersebut didukung oleh Suprijatna (2002) yang menyatakan bahwa tersedianya protein dan lemak yang memadai dalam ransum mengakibatkan meningkatnya bobot folikel, yang berdampak pada laju pendewasaan folikel, sehingga mengakibatkan meningkatnya jumlah folikel memasuki fase pendewasaan.

\section{Jumlah dan Bobot Folikel}

Jumlah dan bobot folikel dengan diameter $\geq 1 \mathrm{~cm}$ pada umur 36 minggu ratarata untuk perlakuan $\mathrm{R}_{0}, \mathrm{R}_{1}, \mathrm{R}_{2}, \mathrm{R}_{3}$ dan $\mathrm{R}_{4}$ sebesar 6,$25 ; 5,50 ; 5,75 ; 6,00$ dan 6,50 butir, sedangkan untuk bobot folikel nya mempunyai bobot rata-rata 34,$30 ; 32,25$; 32,$49 ; 33,90 ; 34,83$ g/ekor (tabel 2).

Penambahan minyak ikan lemuru dalam ransum tidak berpengaruh nyata ( $P>0,05)$ pada jumlah dan bobot folikel dengan diameter $\geq 1 \mathrm{~cm}$, hal ini disebabkan bahan pembentuk yolk terdiri dari zat-zat nutrisi yang ada dalam ransum, terutama protein dan lemak. Protein dalam ransum dibuat iso protein, sedangkan untuk pembentukan dan pertumbuhan folikel yang cepat membutuhkan bahan yolk yang berupa lipoprotein. Pertumbuhan folikel salah satunya sangat dipengaruhi oleh protein ransum, sehingga hal tersebut merupakan salah satu faktor penyebab tidak berpengaruh nyata diantara 
perlakuan. Hal ini sesuai dengan hasil penelitian Suprijatna (2002) yang menyatakan bahwa tersedianya protein dan lemak yang memadai dalam ransum mengakibatkan meningkatnya laju pendewasaan folikel, sehingga mengakibatkan meningkatnya jumlah folikel yang memasuki fase pendewasaan.

Jumlah dan bobot folikel dengan diameter $\geq 1 \mathrm{~cm}$, bobot dan panjangnya sangat proporsional dengan bobot dan panjang oviduct. Hal ini sesuai dengan hasil penelitian Hocking (1997) dalam Haryadi (1999)yang menyatakan bahwa jumlah folikel yang sedang tumbuh "yellow yolk" dipengaruhi oleh besar ukuran oviduct, kemudian dinyatakan pula bahwa besar ukuran dipengaruhi oleh hormon gonadotropin dan estrogen.

Jumlah folikel yang berkembang cepat "yellow yolk" menunjukkan laju produksi. Ayam yang mempunyai produksi telur tinggi memiliki "yellow yolk" yang lebih banyak dari pada ayam yang produksinya rendah, ayam leghorn yang mempunyai produksi tinggi mempunyai jumlah "yellow yolk" 6,82 butir sedangkan yang produksinya rendah 5,89 butir (Zakaria et al., 1999).

Jumlah dan bobot folikel tertinggi dicapai oleh perlakuan $\mathrm{R}_{4}$ yang mendapat penambahan minyak ikan lemuru tertinggi (6\%) kemudian diikuti oleh $\mathrm{R}_{0}, \mathrm{R}_{3}, \mathrm{R}_{2}$ dan $\mathrm{R}_{1}$ (tabel 2). Hal ini disebabkan salah satunya yaitu karena konsumsi energi dan asam lemak tertentu khususnya omega-3 dalam ransum $\mathrm{R}_{4}$ lebih tinggi dibandingkan dengan perlakuan lainnya, sehingga hal ini dapat memacu perkembangan folikel yang meliputih jumlah dan ukuran. Menurut pendapatGrobas et al. (1999) bahwa ransum kaya asam lemak dapat meningkatkan bobot telur dengan menstimulasi sintesis protein "oviduct". Pendapat tersebut didukung oleh
Nalbandov, (1990); Linder, (1992) dan Van Elswyk (1997), yang menyatakan pembentukan telur memerlukan zat pakan yang lengkap, dan pemanfaatan asam lemak tidak jenuh khususnya omega-3 diduga dapat mempercepat proses pematangan folikel, dengan jalan mengotrol regulasi pembentukan VLDLkolesterol dan regulasi hormonal, sehingga dengan cepat terbentuk folikel yang matang.

Perlakuan pada ransum $R_{1}, R_{2}$ dan $R_{3}$ mempunyai jumlah dan bobot folikel yang lebih kecil dibanding $\mathrm{R}_{0}$, hal ini disebabkan karena konsumsi ransum pada perlakuan $R_{1}, R_{2}$ dan $R_{3}$ lebih rendah, sehingga ketersediaan bahan pembentuk yolk terutama protein lemak dan energi lebih rendah pula. Proses pembentukan yolk pada folikel fase 1 sangat ditentukan oleh protein, karena pada fase ini bahan yang disekresikan untuk pembentukan yolk adalah protein, kemudian untuk fase perkembangan folikel berikutnya selain sekresi protein dibutuhkan sekresi lemak untuk memacu perkembangan folikelnya. Hal ini sesuai dengan pendapat Robinson et al. (1993),bahwa ovarium sangat sensitif terhadap tersedianya ransum. Meningkatnya taraf protein pada ransum mengakibatkan meningkatnya laju pertumbuhan folikel, sehingga jumlah folikel yang masuki fase pendewasaan "yellow yolk" meningkat jumlahnya. Pendapat tersebut didukung oleh Suprijatna (2002), bahwa pada saat meningkatnya laju pertumbuhan folikel yang cepat terjadi peningkatan penimbunan bahan yolk yang berupa lipoprotein yang berasal dari protein dan lemak ransum yang dikonsumsi, sehingga mengakibatkan meningkatnya jumlah folikel yang memasuki fase pendewasaan. 


\section{Siklus Ovulasi}

Siklus ovulasi selama penelitian untuk : $\mathrm{R}_{0}, \mathrm{R}_{1}, \mathrm{R}_{2}, \mathrm{R}_{3}$, dan $\mathrm{R}_{4}$ yaitu rata-rata sebesar 23,64;24,27;24,12;23,84; 23,47 jam dapat dilihat pada Tabel 2 . Penambahan minyak ikan lemuru dalam ransum berpengaruh nyata $(\mathrm{P}<0,05)$ mempercepat siklus ovulasi, hal ini disebabkan minyak ikan mengandung lemak dan asam lemak yang sangat dibutuhkan untuk proses perkembangan telur.

Kronologis terjadinya ovulasi dipengaruhi oleh adanya hormon estrogen, FSH dan LH yang berperan membantu mempercepat perkembangan atau pemasakan folikel di ovarium. Semakin tinggi penambahan minyak ikan lemuru dalam ransum penelitian, mempunyai pola kecenderungan semakin mempercepat siklus ovulasi. Hal ini disebabkan karena lemak yang ada dalam minyak ikan lemuru akan dihidrolisis menjadi kolesterol dan asam lemak kemudian yang kemudian dibawa melalui sistem peredaran darah menuju ovarium untuk selanjutnya terjadi proses perkembangan folikel dengan adanya hormon estrogen. Semakin tinggi estrogen semakin tinggi produksi LH, ketinggian kadar LH dapat menyebabkan terjadi proses ovulasi pada folikel yang masak. Terjadi terlepasnya FSH dan LH secara simultan menyebabkan terjadinya ovulasi.

Ovulasi selain dipengaruhi oleh ritme pemsakan folikel di ovarium juga dipengaruhi oleh ritme hormon yang dilepaskan oleh hipotalamus yaitu FSH dan LH yang mempengaruhi aktivitas ovarium, dimana hasil akhirnya adalah ovulasi dan oviposisi. Hal ini sesuai dengan pendapat Linder (2001), bahwa pembentukan sebutir telur memerlukan nutrisi yang lengkap dan pemanfaatan asam lemak tidak jenuh rantai panjang (PUFA), dibutuhkan dalam esterifikasi kolesterol plasma sebagai materi pusat lipoprotein. Lipoprotein terdapat dalam plasma darah mempunyai struktur inti lipid mengandung trigliserida dan kolesterol. Kolesterol merupakan substrat untuk pembentukan zat-zat esensial termasuk asam empedu yang dibuat oleh hati yang merupakan rute utama untuk hormon-hormon steroid (glukokortikoid dan aldosteron). Kedua ritme tersebut akibatnya akan mempercepat siklus ovulasi yang berdampak pada produksi. Semakin cepat waktu yang dibutuhkan untuk membentuk sebutir telur maka semakin tinggi kesempatan untuk memperoleh produksi yang tinggi. Hasil serupa juga ditemui pada penelitian Saerang (1997)tentang penggunaan minyak ikan lemuru dalam ransum puyuh ternyata memberikan kecenderungan produksi telur yang lebih baik.

Siklus ovulasi tercepat dicapai oleh ayam yang diberi perlakuan ransum $R_{4}$ yang mendapat penambahan minyak ikan lemuru tertinggi (6\%) kemudian diikuti oleh $\mathrm{R}_{0}, \mathrm{R}_{3}, \mathrm{R}_{2}$ dan $\mathrm{R}_{1}$ (Tabel 2). $\mathrm{R}_{4}$ berbeda nyata $(\mathrm{P}<0,05)$ dengan $\mathrm{R}_{1}, \mathrm{R}_{2}$ dan $\mathrm{R}_{3}$ tetapi tidak berbeda nyata $(\mathrm{P}>0,05)$ dengan $R_{0}$. Hal ini kemungkinan disebabkan pada $\mathrm{R}_{0}$ salah satunya mempunyai konsumsi ransum yang sangat tinggi dibandingkan dengan perlakuan lainnya (Tabel 2). Tingginya konsumsi ransum $\mathrm{R}_{0}$ menyebabkan persediaan kandungan gizi untuk pembentukan telur semakin banyak tersedia, yang pada akhirnya dapat mendukung siklus ovulasi lebih cepat karena adanya rangsangan dari zat nutrisi tersebut yang membantu proses perkembangan folikel. Pendapat ini sesuai dengan Nesheim et al. (1999)bahwa produksi telur sangat dipengaruhi oleh tercukupinya kandungan nutrisi ransum yang diberikan sehingga akan 
menyebabkan proses metabolisme berjalan secara optimal, hal ini akan berdampak pada pada produksi yang meningkat. Siklus ovulasi yang cepat akan berdampak pada produksi telur yang tinggi, hal ini seiring dengan produksi yang dihasilkan selama penelitian. Pendapat tersebut didukung oleh Yuwanta (2004) yang menyatakan bahwa pembentukan kuning telur merupakan proses terakumulasinya kuning telur dari sebuah folikel ovarium. Proses ini memerlukan waktu yang cukup lama, dan hampir 2/3 komposisi kuning telur terdiri atas lipoprotein yang kaya akan trigliserida merupakan sintesis asam lemak di hati yang dikontrol oleh hormon estrogen, kemudian oleh darah diakumulasikan di ovarium sebagai folikel atau ovum yang dinamakan "yolk".

Rata-rata siklus ovulasi dalam penelitian ini untuk mendapatkan sebutir telur dibutuhkan waktu 23,87 jam, hal ini berarti lebih cepat dari acuan standar yang dinyatakan oleh Nesheim et al. (1999)dimana untuk membentuk sebutir telur dibutuhkan waktu antara oviposisi berurutan sekitar 26,5 jam dengan kisaran 23-31,7 jam. Menurut Sidadolog (2001) dan Yuwanta (2004), interval waktu untuk membentuk sebutir telur dibutuhkan waktu 24-27 jam semakin panjang interval antar oviposisi maka semakin rendah intensitas produksinya. Jadi siklus ovulasi yang dimiliki ayam penelitian ini mempunyai siklus ovulasi yang lebih pendek (23,7 jam) sehingga ayam tersebut dikategorikan ayam yang mempunyai produktivitas tinggi. Hal ini salah satunya mungkin disebabkan cadangan bahan penyusun telur atau nutrisi ransum terutama lemak dan asam lemak yang dibutuhkan untuk pembentukan telur banyak tersedia.

\section{KESIMPULAN}

Penambahan minyak ikan lemuru dalam ransum ayam petelur sampai dengan $6 \%$ tidak mempengaruhi karakteristik folikel, tetapi dapat mempercepat siklus ovulasi. Penambahan minyak ikan lemuru dalam ransum ayam petelur sampai dengan 6\% dapat direkomendasikan kepada peternak ayam petelur dan diharapkan dapat mempunyai nilai tambah bagi peternak maupun konsumen.

\section{DAFTAR PUSTAKA}

Amrullah, I.K. 2003. Nutrisi Ayam Petelur. Lembaga satu Gunung Budi. Institut Pertanian Bogor. Bogor.

Hargis, S.P. 2001. Modifying egg yolk cholesterol in the domestic fowl a Review Worlds. Poultry. Sci. J. 44: 17-29.

Haryadi, 1999. Perkembangan Alat Reproduksi Ayam Petelur Strain Lohmann pada Berbagai dari Umur 22 Minggu sampai 32 Minggu. Skripsi. Fakultas Peternakan Universitas Gadjah Mada. Yogyakarta

Jiang, Z., and J.S. Sim. 1991. Research Note: Egg cholesterol values in relation to theage of laying hens and yolk weights. Poultry Sci. 70: 18381841.

Kwakkel, R.P., B.J. Ducro and W.J. Coops. 1993. Multiphasic analysis of growth of the body and its chemical component in White Leghorn pullets. Poultry Sci. 72: 1421-1432

Linder, M.C. 2001. Biokimia Nutrisi dan Metabolisme dengan Pemakaian Secara Klinis. UI. Press, Jakarta.

Leskanisch, C.O. and R.C. Noble. 1997. Manipulation of the n-3 polyansaturated fatty acid 
composition of avian egg and meat. World's Poultry. Sci. J. 53: 155-183.

Moreng, R.E. and J.S. Avens. 1998. Poultry Science and Production. Reston Publishing Company, Inc. Reston. Virginia.

Nesheim, M.C.,R.E. Austic and L.E. Card. 1999. Poultry Production. $13^{\text {th }}$ Edition. Lea and Febiger, Philadelpia. London.

Nalbandov, A.V. 1990. Fisiologi Reproduksi pada Mamalia dan Unggas. Edisi ke-III. (diterjemahkan Soenarjo Keman). Universitas Indonesia. Jakarta

Robinson, F. E., J. L. Wilson, M. W. Yu, G.M. Fasenko and R. T. Hardin. 1993. The relationship between body weight and reproductive efficiency in meat type chickens. Poultry. Sci. 72: 912-922.

Suhermiyati. 2004. Penggunaan Minyak Hewani dan Nabati Dalam Ransum Ayam Kampung Terhadap Profil Metabolisme Asam Lemak. Laporan Penelitian Proyek Semi-Que. Program Studi Nutrisi dan Makanan Ternak Universitas Jenderal Soedirman Purwokerto.

Supadmo. 2005. Utilization of the Lemuru Fish Oil in Ration as Omega-3 Fatty Acid Resources to improve fat Quality of Meat and Egg. From the Deparment of Animal Nutrien and Feed Science, Animal Husbandry Faculty. Gajdah Mada University. Yogyakarta. Indonesia.

Suprijatna, E. 2002. Manifestasi Taraf Protein Ransum Periode Pertumbuhan Terhadap Pertumbuhan Organ Reproduksi dan Dampaknya Pada Performan Produksi Ayam Petelur Tipe Medium. Disertasi Program Pascasarjana Universitas Padjadjaran Bandung.
Steel, R.G.D. dan J.H. Torrie, 1991. Prinsip dan Prosedur Statistika, PT Gramedia Pustaka Utama, Jakarta. (diterjemahkan oleh B.Sumantri).

Saerang, J.L.P. 1997. Pengaruh Minyak Nabati dan Hewani dalam Ransum Puyuh Petelur terhadap Performan, Daya tetas, Kadar Kolesterol Telur dan Plasma Darah. Tesis Program Pascasarjana Universitas Gadjah Mada. Yogyakarta.

Griffin, J.L. 1998. Manipulation of egg Yolk Cholesterol : a Physiologist's View. World's. Poultry Sci. J. 48 : 102-112.

Grobas, S., J. Mendez, C. de Blas, and G.G. Mateos. 1999. Laying hen productivity as affected by energy, supplemental fat and linoleic acid concentration of the diet. Poultry Sci. 78: 1542-1551.

Zakaria, A.H., T. Miyaki and K. Imai. 1999. The Relationship of clutch length and egg position on the ovarian follicular growth in laying hens. Poultry Sci. 83: 1250-1254. 